\title{
Syagrus coronata (Arecaceae) phenology and the impact of fire on survival and reproduction of the licuri palm
}

\author{
Larry Noblick $^{1 *}$, Sabine Wintergerst ${ }^{2, a}$, Daniela Noblick ${ }^{1, b} \&$ Joanna Tucker Lima ${ }^{1, c}$ \\ ${ }^{1}$ Montgomery Botanical Center, Miami, Florida, U.S.A. \\ ${ }^{2}$ Fairchild Tropical Botanic Garden, Miami, Florida, U.S.A.
}

\begin{abstract}
Three years of reproductive phenological data (1983-1986) were analyzed for 331 licuri palms (Syagrus coronata) in a natural population in Feira de Santana, Bahia, Brazil. Using a one-year subset of the data, we also compared the phenologies of 83 individuals burned by wildfires and 248 unburned individuals to examine the impact of fire on S. coronata. Burned specimens showed slightly delayed fruiting compared to non-burned specimens, but a randomization test showed no significant difference between the two groups, suggesting that licuri palms are capable of surviving wildfires with almost no interruption to their phenological cycles.
\end{abstract}

Additional key words: wildfires, flowering, fruiting.

Resumo (Fenologia de Syagrus coronata (Arecaceae) e o impacto do fogo na sobrevivência e reprodução do licuri) - Foram analisados três anos (1983-1986) de dados de fenología reprodutiva para 331 palmeiras de licuri (Syagrus coronata) numa população natural em Feira de Santana, Bahia, Brasil. Usando um subconjunto dos dados de um ano dessas populações, foi comparada a fenologia de 83 indivíduos que foram queimados com a de 248 indivíduos que não foram queimados a fím de avaliar o impacto dos incêndios na fenologia de $S$. coronata. Indivíduos que foram queimados apresentaram uma frutificação ligeiramente tardia em comparação aos indivíduos que não foram queimados, mas uma avaliação randomizada revelou que não há diferença significativa entre os dois grupos, sugerindo que os licuris sejam capazes de sobreviver a incêndios florestais quase sem interrupção de seus ciclos fenológicos.

Palavras-chave adicionais: incêndios, floração, frutificação.

Phenology, or the monitoring, understanding and prediction of the timing of recurrent biological events such as migration in birds or leafing, flowering, and fruiting in plants (Rosenzweig et al. 2008; Morellato et al. 2016) has gained prominence in environmental science research in recent years as a tool for understanding nature's response to a changing climate. A broad review of the current state of phenology studies in South and Central America (Morellato et al. 2013) found that tropical moist forests are by far the most widely studied ecosystem, while phenological studies in other vegetation types (e.g., caatinga, pantanal, or tropical savanna) are poorly represented. Humid tropical forest ecosystems continue to be a frequent focus of phenological studies in palms even today: e.g., Oenocarpus bataua Mart. (Rojas-Robles \& Stiles 2009), Butia eriospatha (Mart. ex Drude) Becc. (Nazareno \& Reis 2012), Syagrus romanzoffiana (Cham.) Glassman (Freire et al. 2013; Mariano \& Christianini 2016), Mauritia flexuosa L.f. (Rosa et al. 2013; Mendes et al. 2017), and Attalea phalerata Mart. ex Spreng. and A. speciosa Mart. ex Spreng. (Tucker Lima et al. 2018). A few recent phenology papers from tropical savanna study flowering and fruiting in Butia (Becc.) Becc. and Syagrus Mart. palm species (Silva \& Scariot 2013; Guilherme et al. 2015; Bruno et al. 2019)

\footnotetext{
${ }^{*}$ Corresponding author: larryn@montgomerybotanical.org;

awintergerst.sabine@gmail.com; bdnoblick002@gmail.com; cjoannat@montgomerybotanical.org

Corresponding editor: Alessandro Rapini

Submitted: 9 Dec. 2019; accepted: 20 Apr. 2019

First published: 26 June 2020; final version: 10 July 2020
}

and a single phenological study in the pantanal (Fava et al. 2011) examines flowering in Attalea phalerata and Bactris glaucescens Drude. In addition to three phenological studies from the caatinga cited in Morellato et al. (2013), we found only one other published study from the caatinga that investigated reproductive phenology in Syagrus vagans (Bondar) A.D. Hawkes (Lopes 2007). As far as we know, no phenological study has been published on Syagrus coronata (Mart.) Becc., a common palm native to the caatinga and the subject of this study.

Many animals rely on the timing of flowering and fruiting to survive, making plant phenology an important aspect of ecosystem ecology. Various birds, mammals, insects, and other wildlife depend on flowers and fruits for nourishment, the timing of which is critical to feed their young and complete their life cycles. As humans, our own food supply and economy depend on the specific timing of these events, as we count on different fruits and seeds to be available at specific times of the year for harvesting and marketing. Other than food and commerce, there is also a growing scientific interest in using phenological traits to separate taxonomic groups or species (Panchen et al. 2014). Interest in phenology continues to grow among climate change scientists as well. As earlier leafing and flowering times keep step with rising temperatures, phenology becomes one of the most important indicators of climate change (Menzel et al. 2006; Wolkovich \& Ettinger 2014).

This paper details the results of a study exploring the phenology of Syagrus coronata, and how local conditions, e.g. wildfires, impact its normal phenological 
cycles. During our phenological study of Syagrus coronata, unplanned and unexpected wildfires burned through portions of the study population in Bahia, and many of the palms under observation were damaged. Fire is a natural phenomenon in many tropical ecosystems around the world (Morellato et al. 2016). Wildfires can have natural or anthropogenic origins. Natural fires are rare in the caatinga vegetation (Sampaio 1995; Althoff et al. 2016), but anthropogenic wild fires are common due to slash and burn itinerate agriculture, cattle production on native pasture and firewood production (Sampaio 2003).

Several key environmental factors can be modified by a severe fire, such as temperature, soil moisture, and soil chemistry (Paritsis et al. 2006). Depending on the plant community, fire can stimulate flowering and fruiting (Pausas et al. 2004) and germination (Williams et al. 2005). Alternately, it may depress the availability of large seeded fruits (Barlow \& Peres 2006) and destroy buds, flowers, and fruits. Fire can alter the surrounding vegetation structure in such a way that it results in accelerated plant reproductive phenology (Paritsis et. al. 2006), shifting the starting date of flowering and fruiting. Fire can also affect the timing and the amount of fruit set by changing environmental variables such as increased light and temperature and increased available nutrients (White et al. 1991; Kauffman et al. 1993; Bond \& van Wilgen 1996). Among land plants, fire sensitivity varies broadly from one species to another (Hoffman 1998; Lucena et al. 2015). Wildfire-induced changes can be key for management and conservation practices (Andersen et al. 2005), as fire may favor the native or exotic invasive species (D'Antonio 2000). Unplanned fire events during our study presented an excellent opportunity to assess $S$. coronata's response to fire in terms of phenology.

In this study, we address two main questions: (1) What are the typical flowering and fruiting cycles of S. coronata, licuri, in its natural habitat in Bahia, Brazil, and how do these flowering and fruiting events synchronize with the dry and rainy seasons? And, (2) How does fire affect $S$. coronata survival and phenology?

\section{MATERIALS AND METHODS}

Study site. The study site (Figure 1) is located on the campus of the Universidade Estadual de Feira de Santana (UEFS), just north of the city center of Feira de Santana, Bahia, Brazil, along highway BR-324 (S12 $\left.11^{\prime} 41^{\prime \prime}-12^{\circ} 11^{\prime} 56^{\prime \prime}, \mathrm{W} 38^{\circ} 57^{\prime} 57^{\prime \prime}-38^{\circ} 58^{\prime} 34^{\prime \prime}\right)$ and just south of the Novo Horizonte subdivision. The campus lies in a transitional zone between the more humid Atlantic forest and the much dryer caatinga vegetation. The campus's nearly flat relief and sandy clay soils support many caatinga species, including licuri. The climate according to Köppen and Geiger is classified as Aw, a tropical savanna with dry-winter characteristics (pt.climate-data 2018). The region has an average annual temperature of $23^{\circ} \mathrm{C}$ and an annual average rainfall of $888 \mathrm{~mm}$ (Figure 2).

Feira de Santana has a distinct rainy and dry season. The municipality receives rains concentrated within two seasonal peaks, one in May (late fall, beginning of winter) and the other in November (late spring, beginning of summer) (Figure 2). For Feira de Santana, the absolute driest months are September and October (pt.climate-data.org 2018). This was the time of year when wildfires occurred in 1984. The coldest temperatures for the area are in June-August and the warmest are in November-March (Figure 2).

In the second year of our study, a series of wildfires burned through different portions of the study area over a three month period (October thru December of 1984), which instead of being a disappointing setback, added an additional opportunity to explore. These wildfires were primarily ground fires, reducing the surrounding vegetation to ashes and hot enough to char the bases of the licuri palms and burn into the canopies of many. I (first author) had been visiting the university since 1980 , and this was the first time that I had seen this many wildfires on campus. We have no recorded history of fires on the campus, although the eroded shape of some of the palm stems suggests they may have burned before.

Species characterization. Syagrus coronata, locally known as licuri, has a distribution that extends from the dry caatinga vegetation east of the Rio São Francisco in Bahia, Brazil, throughout most of eastern and central Bahia, and from southern Pernambuco, through the states of Sergipe and Alagoas, to northern Minas Gerais (i.e., north of the Rio Jequitinhonha). In northern Bahia, Sergipe, and Alagoas, populations of this species are distributed as far as the coastal restinga vegetation; but south of Salvador, Bahia, licuri populations stop at the drier transitional areas and do not invade the wetter coastal Atlantic rain forest, nor its adjacent restingas. This species is one of the few palms that survive the arid caatinga region, but it does best in transitional regions (Noblick 2017). Syagrus coronata is a slow-growing, medium-sized palm with $15-30$ leaves in its crown and is distinguished by very short internodes, an angular trunk, thick flat, woody sheath fibers, and a curious twisted leaf arrangement that gives the appearance of five ascending spires or columns of leaves (Noblick 2019), which inspired Martius to name the palm "coronata", meaning crown.

Syagrus coronata is an important species of the caatinga region (Carvalho et al. 2016) and deserves further study. Bondar $(1938,1942)$ championed the usefulness of $S$. coronata, reporting that the palm's apical meristem, sometimes referred to as the palm heart, fruit, and nut are edible, the leaves provide wax, the seeds are used for extracting oil for soap and other products, and the endocarp (nut) is used in regional handicrafts. During droughts, licuri leaves are ground 

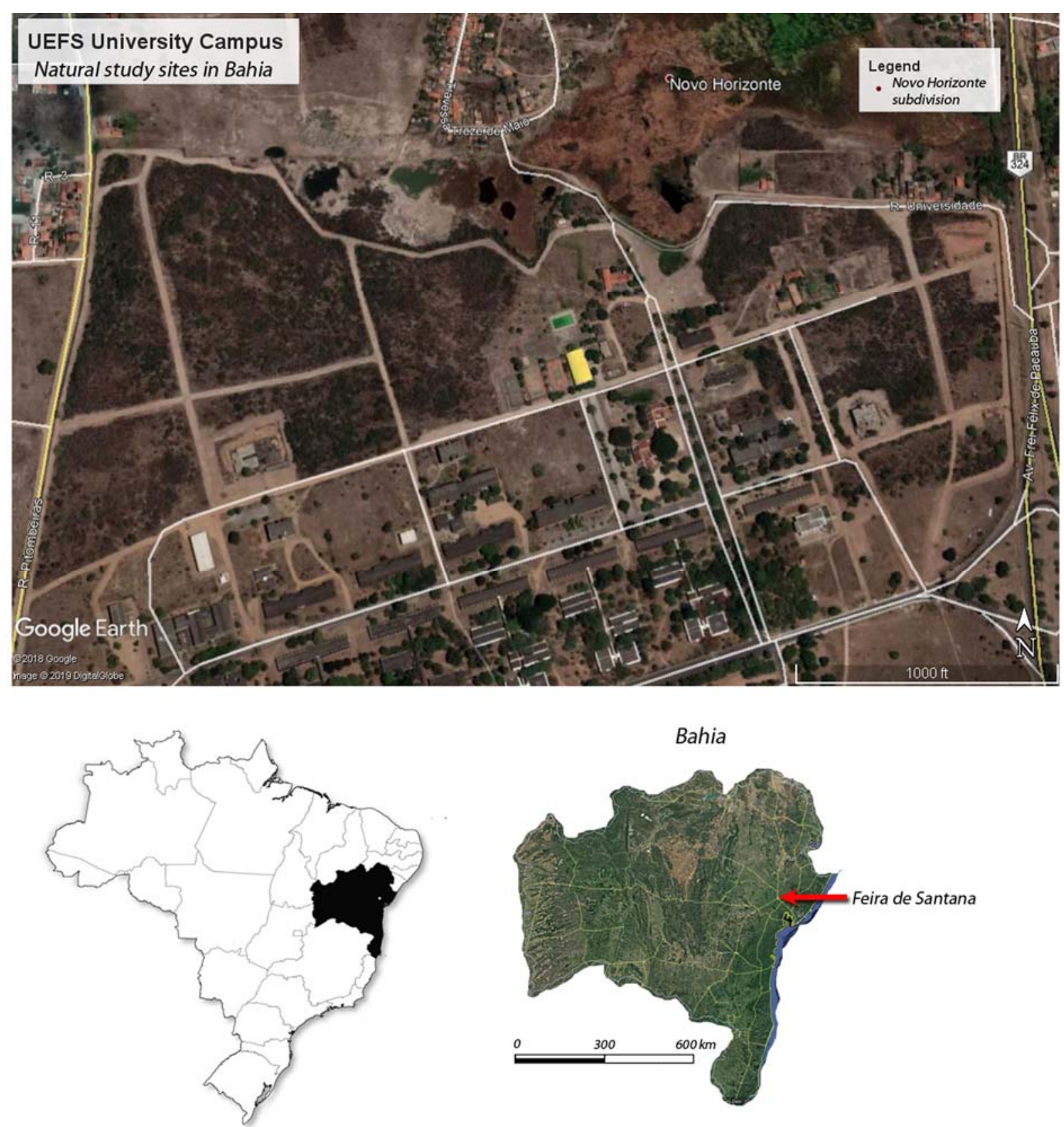

Figure 1. Location of the State of Bahia in Brazil and the town of Feira de Santana with an aerial view of the UEFS campus. Research on Syagrus coronata was carried out in the natural areas of the campus that have not yet been cleared nor developed.

up, mixed with other plants and fed to livestock. Even during the driest spells, this palm will flower and produce fruits, which have an edible, mucilaginous, sweetish, fibrous mesocarp that is chewed then discarded. The oily seeds are collected in large quantities for food, and can be made into a sugary sweet "cocada". The seeds (endosperm or nut) are often strung into long "rosaries" and eaten at leisure. They are also pressed to extract oil for cooking and lighting oil and for the manufacture of other assorted products, as in the perfume industry. The crushed and broken seed can also be fed as a daily ration to domesticated fowl. The leaves of licuri are used extensively for covering rural shelters, to fabricate doors and walls, and local people use parts of the leaf, especially the leaflets, for making hats, fans, baskets, dusters, sleeping mats, etc. The leaf wax is of very high quality, similar to that collected from carnaúba palms, Copernicia prunifera (Mill.) H.E.Moore (Bondar 1942). In an emergency, a substitute flour, "farinha", can be pounded and sifted from its trunk to prevent starvation.

Phenological observations. Phenology observations were collected between July 1983 and June 1986 on a natural population of licuri palms, S. coronata, growing on undeveloped portions of the UEFS campus. During that time, the first author recorded monthly observations on the flowering and fruiting cycles of 331 randomly selected licuri palms. The randomly chosen adult trees were numbered by 


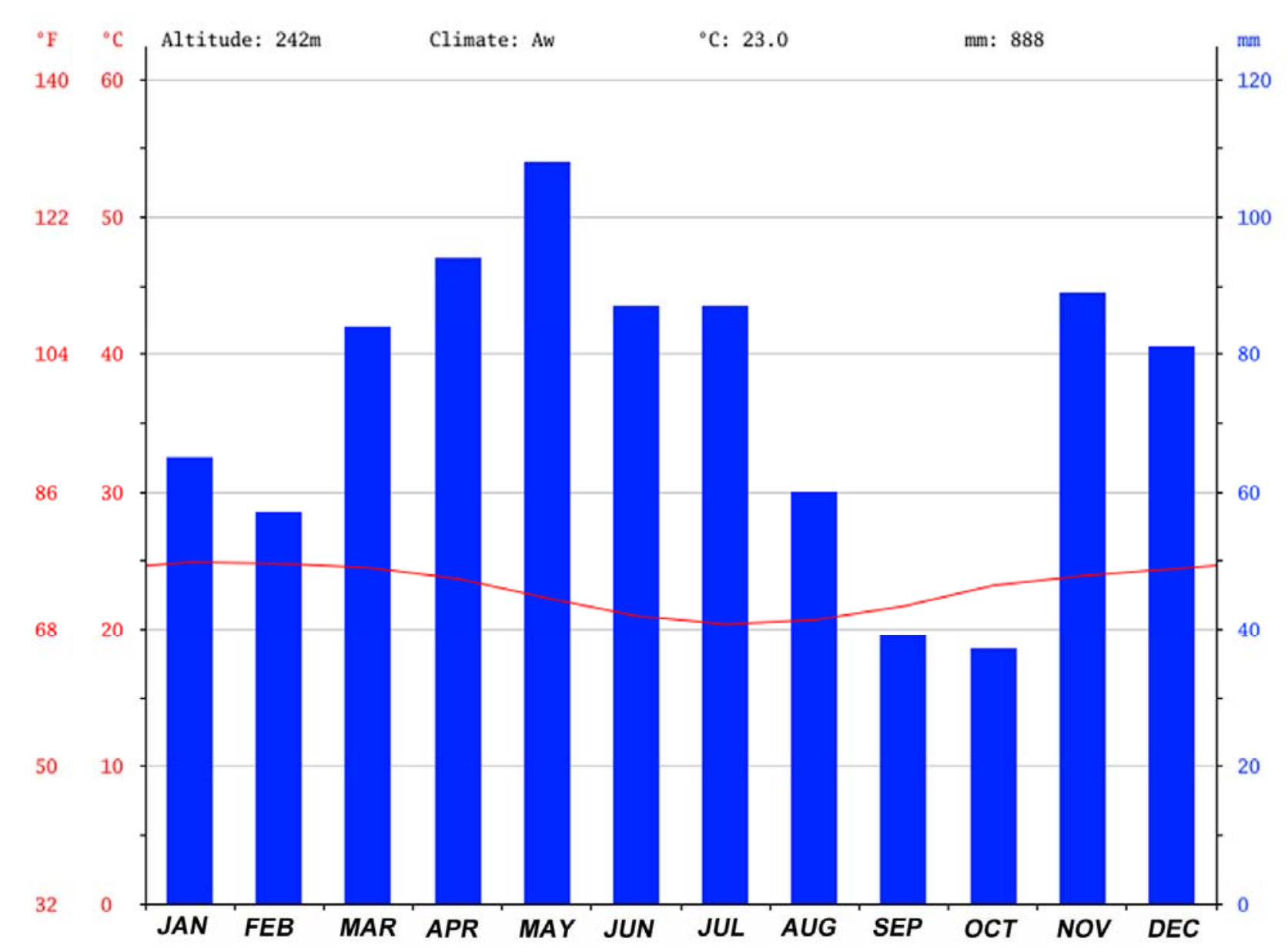

Figure 2. Climatic condition chart. The undulating line represents monthly temperature $\left({ }^{0} \mathrm{~F} /{ }^{\circ} \mathrm{C}\right)$ recorded on the primary y-axis, and bars show monthly rainfall $(\mathrm{mm})$ recorded for Feira de Santana, Bahia, Brazil, on the secondary y-axis.

smoothing off a portion of the woody stem or petiole bases with a machete and assigning an identification number with a permanent marking pen. The palms were distributed around 2-5 $\mathrm{m}$ from one another. At monthly intervals, we recorded if a palm had initials (newly emerging peduncular bracts), inflorescences, or infructescences. Very few actual mature fruiting observations were recorded, due to the early harvesting of this stage by local people and animals. Therefore the fruiting stage refers to both green and mature fruits. Observations continued for three years, missing only one month in October 1985.

Data analysis. To examine the phenology of $S$. coronata, we included all data collected over the 3year period, between July 1983 and 1986. We used circular statistics (Batschelet 1981; Morellato et al. 2010) to determine seasonality of the three reproductive stages (initials, flowering, and fruiting). To calculate circular statistic parameters for each reproductive stage, we converted months to angles at $30^{\circ}$ intervals, starting with $15^{\circ}$ for January successively through $345^{\circ}$ for December and then converted angles into radians (Morellato et al. 2010). A reproductive stage is considered seasonal if the data is non-uniformly distributed. To test for uniformity, we used the Rayleigh test (Morellato et al. 2010). Additionally, we estimated the mean date for each phenophase by calculating the mean angle. We estimated temporal synchrony by calculating the mean vector length (rho) for non-uniformly distributed data subsets. The length of the mean vector assumes values between 0 and 1 and measures concentration of the data around the mean angle. High values indicate high temporal synchrony and therefore low variation among individuals. Circular statistics were performed using the $\mathrm{R}$ package circular 0.4-93 (Agostinelli \& Lund 2017).

For analyzing the effects of burning on phenology, we isolated a 1-year period from October 1984 to September 1985 (i.e., during and nine months following the wildfires), when 83 palms were damaged by a series of wildfires that occurred during a particularly long dry season from October to December 1984. During this period, another 248 palms were left unscathed by the wildfires. In order to compare phenological parameters between burned and unburned individuals, we used an algorithm for a randomization test provided by Dodonov (2017) that estimates the following parameters for burned and unburned individuals, respectively: the activity index, or mean 


\section{$\longrightarrow \%$ initials $\longrightarrow$ - $\sim$ flowering fruiting}

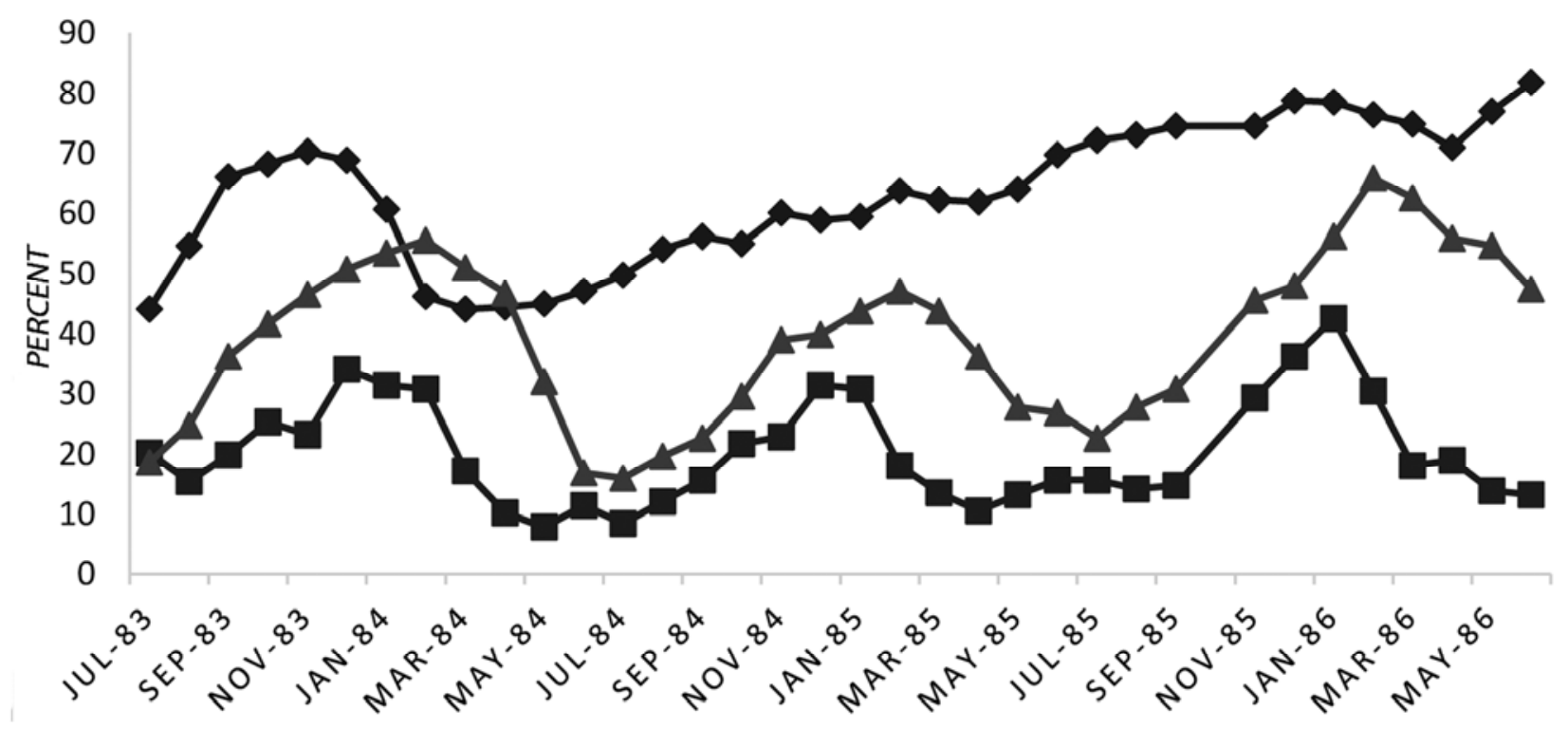

Figure 3. Percentage of Syagrus coronata palms $(\mathrm{n}=331)$ exhibiting each reproductive stage: initializing inflorescences (initials), flowering, and fruiting by month over a 3-year period (July 1983-June 1986) in Feira de Santana, Bahia, Brazil.

proportion of individuals expressing a given reproductive stage (Dodonov et al. 2018), and the mean date, which is retrieved by calculating mean angle and length of the mean vector as a measure of variation among individuals. During each randomization, individuals are randomly classified as burned and unburned and significances are calculated by comparing the randomized values to the observed ones. We used 4999 randomizations. Furthermore, we used an additional algorithm provided by Dodonov (2017) to assess the significance of vector lengths for burned and unburned palms separately, where the observed mean vector length for each population was compared with the distribution of vector lengths obtained through randomization. All statistical analyses were performed using the software R 3.5.1 (R Core Team 2018).

\section{RESULTS}

Phenology. The line graphs and rose diagrams reveal that $S$. coronata initiates inflorescences, flowers, and fruits nearly all year long (Figures 3 and 4). Flowering peaks happened around December and January (early summer; Figures 3 and 4B), followed by fruiting peaks in January-March (summer, late summer rainy season; Figures 3 and $4 \mathrm{C}$ ).

These results are supported by the circular statistical analyses. The Rayleigh test confirms that palms from the UEFS population produce initials all year long with no marked seasonality (Rayleigh test Bahia: $p=0.05$; Figure 4A). The abrupt drop in initials during October (Figure 4A) is due to missing data from October 1985. In other words, each of the monthly "pie" sections of the rose diagrams (Figure 4A) represents three years of accumulated data, but the October "pie" section is smaller because it is missing data for that month.

Although flowering and fruiting occur all year as indicated by the line and circular graphs (Figures 3 and 4), we observed a distinct seasonality with annual seasonal peaks of flowering and fruiting. At the UEFS campus, flowering is concentrated during spring and summer, October-February (Rayleigh test: $p<0.001$; Figure 4B) with peaks in December and January. Fruiting is greatest in summer and fall (Rayleigh test: $p$ $<0.001$; Figure 4C) with peaks in January-March. Nonetheless, small mean vector lengths (flowering: rho $=0.25$, fruiting: rho $=0.14$ ) indicate low temporal synchrony and high variation among individuals.

Wildfire effects. The line graphs, which compare the activity index of burned and unburned palms for each reproductive state throughout the year (Figure 5), demonstrate no difference between the phenologies of these two groups. This observation is confirmed by the randomization test, which revealed no statistical differences between the two groups neither in their activity index nor in their timing. The mean vector lengths also showed no significant difference between burned and unburned palms (Table 1). When we examined the mean vector length within burned and unburned populations, the annual distribution of flowering and fruiting differed significantly from a uniform distribution for both groups (flowers burned: $p$ $=0.002$, unburned: $p=0.01$, fruits burned: $p<0.001$, unburned: $p<0.001$ ), whereas initials are uniformly distributed during the year (burned: $p=0.08$, unburned: $p=0.06$ ). 
Initials S. coronata Bahia (1983 - 1986)

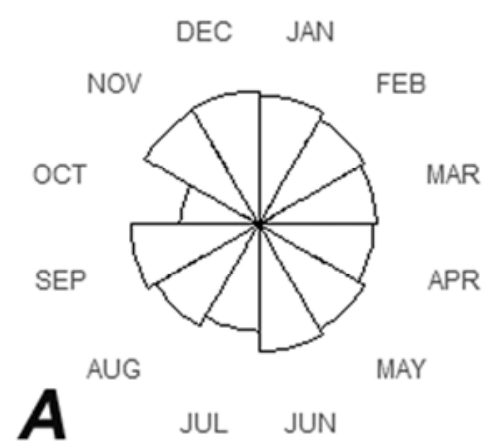

\section{Flowering S. coronata}

Bahia (1983 - 1986)

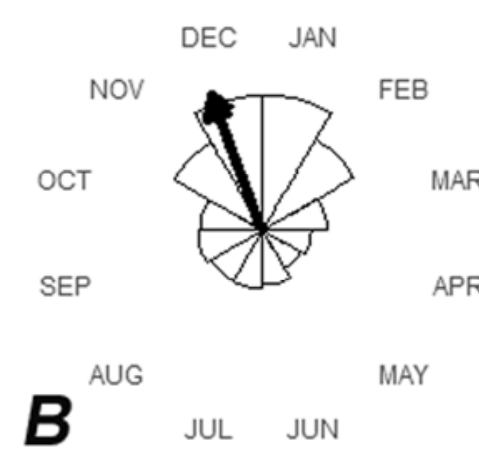

Fruiting S. coronata Bahia (1983 - 1986)

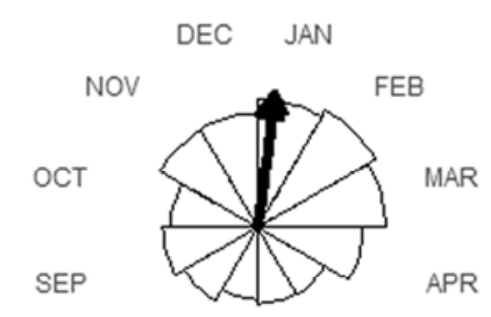

MAY

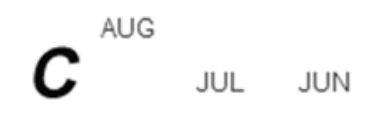

Figure 4. Syagrus coronata phenology: phenology event data on 331 trees in the form of rose diagrams showing the seasonality of the initiating, flowering, and fruiting in Feira de Santana, Bahia, Brazil. Arrows represent the mean angle of all data points represented in each rose diagram. No arrow means the data have a uniform distribution with no significant seasonality, or the arrow length was insignificant $(<0.05$, on a scale of $0-1)$.

\section{DISCUSSION}

To our knowledge, this is the first phenology study of the caatinga palm species Syagrus coronata, commonly known as licuri, other than early casual observations recorded by Bondar (1938). This is also one of the few phenological studies for a caatinga or dry tropical forest species (Morellato et al. 2013). Our results are essential because of the local economic importance of licuri for the humans and the wildlife that depend on it. It helps us to understand the timing of recurrent biological cycles in licuri and the factors that influence them, and uncovers vital information that can be used to better manage and conserve this important species.

Phenology of Syagrus coronata. On the UEFS, Feira de Santana campus, licuri flowering peaks during the wet and warming part of the year (November to January) at the beginning of the summer rainy season. Licuri fruits mature quickly, in only two to four months after flowering (unpublished data from Montgomery Botanical Center in Miami, FL, USA), well before the rainy season reaches its peak and wanes (January to April, summer and fall), giving the fruit optimal time to mature, and for the seedlings to germinate and establish. Our findings in Feira de Santana corroborate previous reports by Bondar (1938) from Bahia's interior, where flowering occurred in the summer and fruiting reached its peak in late summerfall, occasionally extending into early winter.

The fruits of $S$. coronata are classified as zoochoric, since they are mostly distributed by animals (e.g. Lear's Macaw) (Rocha 2009). Arboreal zoochoric plants most often produce their fruits during the rainy season (Munhoz \& Felfili 2007). Thus, it is no surprise that licuri follows the same pattern as other zoochoric species. Other studies on zoochoric palm species in Brazil show similar correlations of flowering and fruiting with their respective rainy season. Even in the Atlantic rainforest, where climate seasonality is low, forest trees followed annual seasonal patterns of reproduction, and flowering and fruiting was concentrated during the wettest months (Morellato et al. 2000). Syagrus pseudococos (Raddi) Glassman of the Atlantic forest reaches its flowering and fruiting peaks during the warmer and wetter months much like S. coronata, but Euterpe edulis Mart. begins to fruit a bit later, at the end of the rainy season (Bencke \& Morellato 2002). Precipitation and fruiting were also significantly correlated for Syagrus glaucescens Glaz. ex Becc. (Miola et al. 2010). Mature infructescences of Butia capitata (Mart.) Becc. also appear in the rainy season (Silva \& Scariot 2013), and the fruit fall of Acrocomia aculeata (Jacq.) Lodd. ex Mart. is generally concentrated from October to January (Scariot et al. 1995), which corresponds to the rainy season in central Brazil. In addition, Tucker Lima et al. (2018) confirmed that Attalea phalerata and A. speciosa both dropped their mature fruits in the wet season. Only Fava et al. (2011) reported Attalea phalerata with ripening fruits during the dry season, which probably means that these ripening fruits became mature and dropped in the rainy season.

Impact of burning on Syagrus coronata. Several studies have investigated the effects of fire on plants in Brazil, mainly in the cerrado habitat (Bencke \& Morellato 2002; Miola et al. 2010; Neves \& Damasceno-Junior 2011; Lucena et al. 2015; Dodonov et al. 2018). During our study, only nine palms died during the 3-year study period. Most deaths resulted from mineral deficiencies, diseases, or human actions with axes, saws, and heavy machinery. Of the 83 palms damaged by burning, only two died as a result, indicating a high tolerance for fire events. Other authors report that fires influence phenology, but only one included burned palms in their analysis (Miola et al. 2010). 


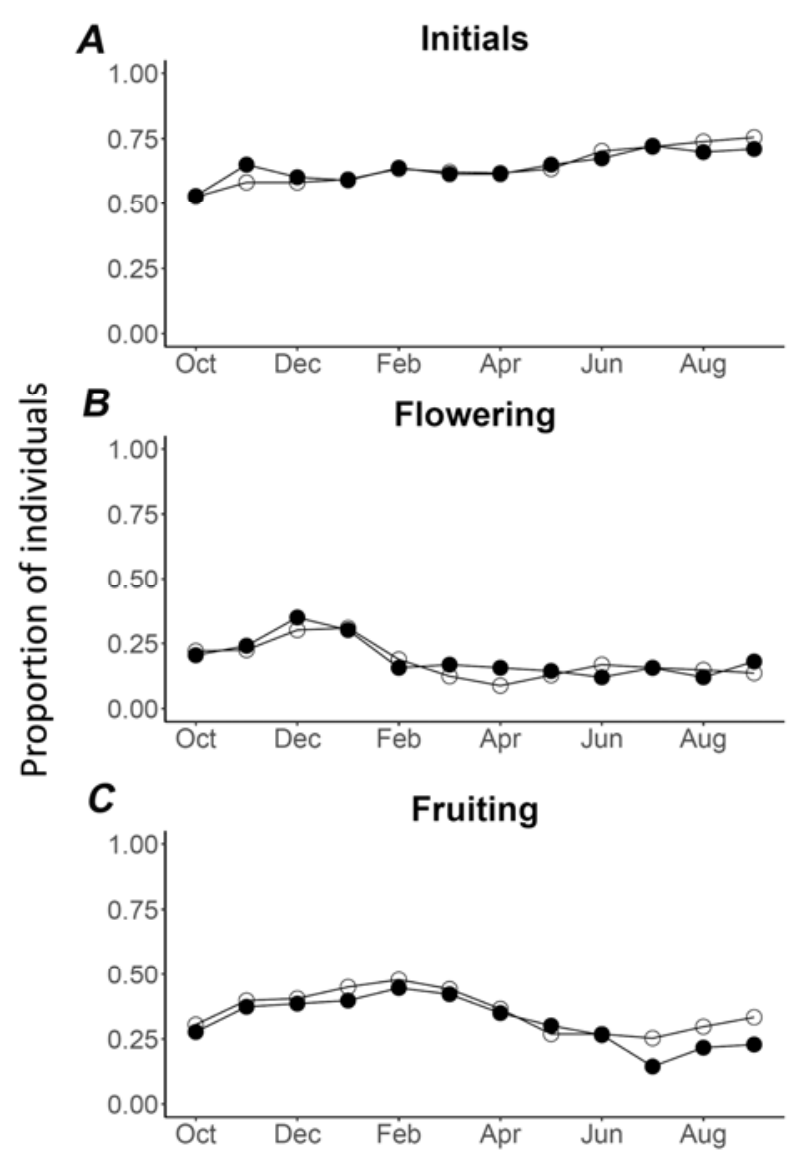

Figure 5. Proportion of individuals expressing a given reproductive stage (activity index) throughout the year from October 1984 to September 1985 for burned (closed black circles) and unburned (open white circles) individuals of Syagrus coronata in Feira de Santana, Bahia, Brazil.

In their article, Miola et al. (2010) identified their study species as S. glaucescens, but based on their study location, "Serra do Cipó", and the fact that their palm had "a growing decumbent stem", this species should be correctly identified as S. duartei Glassman (Lorenzi et al. 2010; Noblick 2017). After a wildfire, Miola et al. (2010) found that S. duartei exhibited intense flowering, but subsequent fruiting was low. They attributed the low fruit set to the destruction of surrounding plants that serve as home and food for the local pollinators (Potts et al. 2003; Miola et al. 2010). Although we recorded fruiting as part of our phenology observations, we kept no detailed records regarding the amount of successful fruit set because the occurrence of wildfires was never anticipated. Our data is not sufficient to rule out other ways that reproduction of burned palms might have been affected. For example, the number of inflorescences or infructescences per palm, or the number of fruits per infructescence might be lower in burned individuals, or the quality of seeds might be lower (Paritis et al. 2006). Nor does our study prove these palms cannot be killed by wildfires, although it suggests a high level of tolerance. Palms may take several years to recover, and many fail in their struggle to recuperate (Bondar 1942). In fact, the waxy leaves of this palm catch fire very easily and burn violently even when young and green (Bondar 1942), thus the crown can be totally destroyed.

Miola et al. (2010) also reported that burned $S$. duartei actually flowered and fruited earlier than nonburned control palms. This corroborates a study by Paritis et al. (2006), in which they found that fire can alter the surrounding vegetation structure in a way that results in an accelerated reproductive phenology. We found no evidence of early flowering or fruiting in burned S. coronata palms. We did find a slight delay in fruiting of our burned vs. unburned palms, but the randomization test proved this difference to be insignificant (Table 1).

In conclusion, this paper is the first phenological study of Syagrus coronata, a caatinga palm species that initializes inflorescences, flowers, and fruits all year round with flowering and fruiting peaks during the rainy season. After a series of unexpected wildfires, Syagrus coronata proved capable of surviving such events, demonstrated by the successful survival of 81 out of the 83 burned palms 18 months after the wildfires and the absence of significant effects on the phenological parameters assessed in this study. Knowledge concerning the phenology of Syagrus coronata contributes valuable information for managing and conserving this important caatinga palm.

Table 1. Summary statistics for the different reproductive stages of burned and unburned Syagrus coronata in Bahia, Brazil, from October 1984 to September 1985. The significance values are the result of the randomization test comparing burned and unburned palms. The activity index represents the proportion of individuals expressing a given reproductive stage, and the vector length measures the variation in the timing of initials, flowering or fruiting among individuals. Lower values indicate higher variation and low temporal synchrony. Significant vector lengths, marked by asterisks, indicate a non-uniform distribution and therefore, pronounced seasonality.

\begin{tabular}{llll}
\hline & Unburned & Burned & Significance \\
\hline Initials & & & \\
Mean activity index & 0.76 & 0.72 & 0.22 \\
Mean date & July 12 & July 17 & 0.85 \\
Vector length & $0.05^{\text {ns }}$ & $0.04^{\mathrm{ns}}$ & 0.38 \\
\hline Flowering & & & \\
Mean activity index & 0.31 & 0.35 & 0.59 \\
Mean date & Dec 7 & Dec 14 & 0.61 \\
Vector length & $0.21 *$ & $0.21 * *$ & 0.94 \\
\hline Fruiting & & & \\
Mean activity index & 0.48 & 0.45 & 0.39 \\
Mean date & Jan 21 & Feb 3 & 0.39 \\
Vector length & $0.14 * * *$ & $0.19^{* * *}$ & 0.16 \\
\hline ns $\mathrm{p} \geq 0.5 . * 0.05>\mathrm{p} \geq 0.01 . * * 0.01>\mathrm{p} \geq 0.001$. & $* * * \mathrm{p}<0.001$.
\end{tabular}




\section{ACKNOWLEDGEMENTS}

We would like to thank the Universidade Estadual de Feira de Santana (UEFS), Feira de Santana, Bahia, Brazil, for the use of the campus to study this very interesting palm in its natural habitat, and Montgomery Botanical Center for their financial and intellectual support.

\section{REFERENCES}

Agostinelli, C. \& Lund, U. 2017. R package 'circular': Circular Statistics (version 0.4-93). Available at: https://r-forge.rproject.org/projects/circular.

Althoff, T.D.; Meeses, R.S.C.; Carvalho, A.L.; Pinto, A.S.; Santiago, G.A.C.F.; Ometto, J.P.H.B.; Rando, C. \& Sampaio, E.V.S.B. 2016. Climate change impacts on the sustainability of the firewood harvest and vegetation and soil carbon stocks in a tropical dry forest in Santa Teresinha Municipality, Northeast Brazil. Forest Ecology and Management 360: 367-375.

Andersen, A.N.; Cook, G.D.; Corbett, L.K.; Douglas, M.M.; Eager, R.W.; Russell-Smith, J.; Setterfield, S.A.; Williams, R.J. \& Woinarski, J.C.Z. 2005. Fire frequency and biodiversity conservation in Australian tropical savannas: implications from the Kapalga fire experiment. Austral Ecology 30: $155-167$.

Barlow, J. \& Peres, C.A. 2006. Effects of single and recurrent wildfires on fruit production and large vertebrate abundance in a central Amazonian forest. Biodiversity and Conservation 15: 985-1012.

Batschelet, E. 1981. Circular Statistics for Biology. Academic Press, London

Bencke, C.S.C. \& Morellato, L.P.C. 2002. Estudo comparativo da fenologia de nove espécies arbóreas em três tipos de floresta atlântica no sudeste do Brasil. Revista Brasileira de Botânica 25: $237-248$.

Bond, W.J. \& van Wilgen, B.W. 1996. Fire and Plants. Chapman and Hall, London.

Bondar, G. 1938. O Licuriseiro, Cocos caronata [sic] Mart. e suas possibilidades na economia brasileira. Boletim do Instituto Central de Fomento Econômico da Bahia 2: 1-18.

Bondar, G. 1942. As cêras no Brasil e o licuri Cocos coronata Mart. na Bahia. Boletim do Instituto Central de Fomento Econômico da Bahia 11: 1-86.

Bruno, M.M.A.; Massi, K.G.; Vidal, M.M. \& Hay, J.V. 2019. Reproductive phenology of three Syagrus species (Arecaceae) in a tropical savanna in Brazil. Flora 252: 18-25.

Carvalho, A.J.A.; Ferreira M.H.S. \& Alves, J.S. 2016. Manual do Licuri. Programa Conca: sustentabilidade, saberes e sabores da caatinga. Editora Áttema. Salvador.

D'Antonio, C.M. 2000. Fire, plant invasions, and global changes. In: H.A. Mooney \& R.J. Hobbs (eds), Invasive Species in a Changing World. Island Press, Washington, DC, p. 65-93.

Dodonov, P. 2017. MonteCaRlo Scripts for Monte Carlo methods in R. GitHub repository. Available from: https://github.com/ pdodonov/MonteCaRlo.
Dodonov, P.; Zanelli, C.B. \& Silva-Matos, D.M. 2018. Effects of an accidental dry-season fire on the reproductive phenology of two Neotropical savanna shrubs. Brazilian Journal of Biology 78(3): 564-573.

Fava, W.; Covre, W. \& Siggrist Y. 2011. Attalea phalerata and Bactris glaucescens (Arecaceae, Arecoideae): phenology and pollination ecology in the pantanal. Flora 206: 575-584.

Freire, C.C.; Closel, M.B.; Hasui, E. \& Ramos, F.N. 2013. Reproductive phenology, seed dispersal and seed predation in Syagrus romanzoffiana in a highly fragmented landscape. Annales Botanici Fennici 50: 220-228.

Guilherme, F.A.G.; Vasconcelos, E.I.; Coelho, C.P.; Ressel, K.; Batista, N.T.F. \& Soza, L.F. 2015. Vegetative and reproductive phenology of Butia purpurascens Glassman (Arecaceae) under the effects of leaf harvesting. Brazilian Journal of Biology 75(1): 77-85.

Hoffman, W.A. 1998. Post-burn reproduction of woody plants in a Neotropical savanna: the relative importance of sexual and vegetative reproduction. Journal of Applied Ecology 35(3): 422-433.

Kauffman, J.B.; Sanford Jr., R.L.; Cummings, D.L.; Salcedo, H.I. \& Sampaio, E.V.S.B. 1993. Biomass and nutrient dynamics associated with slash fires in Neotropical dry forests. Ecology 74: 140-151.

Lopes, V.S. 2007. Morfologia e Fenologia Reprodutiva do Ariri (Syagrus vagans (Bondar) Hawkes) - Arecaceae - Numa Área de Caatinga do Município de Senhor do Bonfim-BA. Dissertation (Masters in Agronomy), Universidade Federal da Paraíba, Areia.

Lorenzi, H.; Noblick, L.R.; Kahn, F. \& Ferreira, E. 2010. Brazilian Flora Lorenzi Arecaceae (Palms). Instituto Plantarum de Estudos da Flora, Nova Odessa.

Lucena, I.C.; Leite, M.B. \& Silva Matos, D.M. 2015. A deciduidade foliar indica a vulnerabilidade de espécies lenhosas ao fogo. Revista Árvore 39: 59-68.

Mariano, V. \& Christianini, A.V. 2016. Reproductive phenology, seed removal and early regeneration in relation to distance from parental plants of a native palm in small Atlantic forest fragments. Acta Botanica Brasilica 30: 176-182.

Mendes, F.N.; Valente, R.M.; Rêgo, M.M.C. \& Esposito, M.C. 2017. Reproductive phenology of Mauritia flexuosa L. (Arecaceae) in a coastal restinga environment in Northeastern Brazil. Brazilian Journal of Biology 77: 29-37.

Menzel, A.; Sparks, T.H.; Estrella, N.; Koch, E.; Aasa, A.; Ahas, R.; Alm-Kubler, K.; Bissolli, P.; Braslavska, O.; Briede, A.; Chmielewski, F.M.; Crepinsek, Z.; Curnel, Y.; Dahl, A.; Defila, C.; Donnely, A.; Filella, Y.; Jatczak, K.; Mage, F.; Mestre, A.; Nordli, O.; Peñuelas, J.; Pirinen, P.; Remisová, V.; Scheifinger, H.; Striz, M.; Susnik, A.; van Vliet, A.J.H.; Wielgolaski, F.-E.; Zach, S. \& Zust, A. 2006. European phenological response to climate change matches the warming pattern. Global Change Biology 12: 1969-1976.

Miola, D.T.B.; Correira, H.V.L.; Fernandes, G.W. \& Negreiros, D. 2010. The effect of fire on phenology of Syagrus glaucescens Glaz. ex Becc. (Arecaceae). Neotropical Biology and Conservation 5: 146-153.

Morellato L.P.C.; Talora, D.C.; Takahasi, A.; Bencke, C.C.; Romera, E.C. \& Zipparro V.B. 2000. Phenology of Atlantic rain forest trees: a comparative study. Biotropica 32: 811-823 
Morellato, L.P.C.; Alberti, L.F. \& Hudson, I.L. 2010. Applications of circular statistics in plant phenology: a case studies approach. In: I.L. Hudson \& M.R. Keatley (eds), Phenological Research: methods for environmental and climate change analysis. Springer, Netherlands, p. 339-359.

Morellato, L.P.C.; Camargo, M.G.G. \& Gressler E. 2013. A review of plant phenology in South and Central America. In: M.D. Schwartz (ed.), Phenology: an integrative environmental science. Springer, New York, p. 91-113.

Morellato, P.C.; Alberton, B.; Alvarado, S.T.; Borges, B.; Buisson, E.; Camargo, M.G.; Cancian, L.F.; Carstensen, D.W.; Escobar, D.F.E.; Leite, P.T.P.; Mendoza, I.; Rocha, N.M.W.B.; Soares, N.C.; Silva, T.S.F.; Staggemeier, V.G.; Streher, A.S.; Vargas, B.C. \& Peres, C.A. 2016. Linking plant phenology to conservation biology. Biological Conservation 195: 60-72.

Munhoz, C.B.R. \& Felfili, J.M. 2007. Reproductive phenology of an herbaceous-subshrub layer of a savannah (Campo Sujo) in the Cerrado Biosphere Reserve I, Brazil. Brazilian Journal of Biology 67: 299-307.

Nazareno, A.G. \& Reis, M.S. 2012. Linking phenology to mating system: exploring the reproductive biology of the threatened palm species Butia eriospatha. Journal of Heredity 103: 842-852.

Neves, D.R.M. \& Damasceno-Junior, G.A. 2011. Post-fire phenology in a campo sujo vegetation in the Urucum plateu, Mato Grosso do Sul, Brazil. Brazilian Journal of Biology 71: 881-888.

Noblick, L.R. 2017. A revision of the genus Syagrus (Arecaceae). Phytotaxa 294: 1-262.

Noblick, L.R. 2019. Syagrus coronata and its twist. Palms 63: 109 112.

Panchen, Z.A.; Primack, R.B.; Nordt, B.; Ellwood, E.R.; Stevens, A.-D.; Renner, S.S.; Willis C.G.; Fahey R.; Whittemore A.; Du Y. \& Davis C.C. 2014. Leaf out times of temperate woody plants are related to phylogeny, deciduousness, growth habit and wood anatomy. New Phytologist 203: 1208-1219.

Paritsis, J.; Raffaele, E. \& Veblen, T.T. 2006. Vegetation disturbance by fire affects plant reproductive phenology in a shrubland community in northwestern Patagonia, Argentina. New Zealand Journal of Ecology 30: 387-395.

Pausas, J.G.; Bradstock, R.A.; Keith, D.A. \& Keeley, J.E. 2004 Plant functional traits in relation to fire in crown-fire ecosystems. Ecology 85: 1085-1100.

Potts, S.G.; Vulliamy, B.; Dafni, A.; Ne'eman, G.; O'Toole, C.; Roberts, S. \& Willmer, P. 2003. Response of plant-pollinator communities to fire: changes in diversity, abundance and floral reward structure. Oikos 101: 103-112.
Pt.climate-data.org 2018. Avaiable at: https://pt.climate-data.org; accessed in: November 2018.

R Core Team. 2018. R: a language and environment for statistical computing. R Foundation for Statistical Computing, Vienna, Austria.

Rocha, K.M.R. 2009. Biologia Reproductiva da Palmeira Licuri (Syagrus coronata (Mart.) Becc.) na Ecorregião do Raso da Cartarina, Bahia. Dissertation (Masters in Silviculture), Universidade Federal Rural de Pernambuco, Recife.

Rojas-Robles, R. \& Stiles, T. 2009. Analysis of a supra-annual cycle: reproductive phenology of the palm Oenocarpus bataua in a forest of the Colombian Andes. Journal of Tropical Ecology 25: 41-51.

Rosa, R.K.; Barbosa, R. I. \& Koptur, S. 2013. How do habitat and climate variation affect phenology of the Amazonian palm, Mauritia flexuosa? Journal of Tropical Ecology 29: 255-259.

Rosenzweig, C.; Karoly, D.; Vicarelli, M.; Neofotis,; Wu, Q.; Casassa, G.; Mensel, A.; Root, T.L.; Estressa, N.; Sequin, B.; tryjanowski, P.; Liu C.; Rawlins, S. \& Imeson, A. 2008. Attributing physical and biological impacts to anthropogenic climate change. Nature 453: 353-357.

Sampaio, E.V.S.B. 1995. Overview of the Brazilian caatinga. In: S.H. Bullock, H.A. Mooney \& E. Medina (eds), Seasonally Dry Tropical Forests. Cambridge University Press, Cambridge, p. 35-63.

Sampaio, E.V.S.B. 2003. Caracterização da caatinga e fatores ambientais que afetam a ecologia das plantas lenhosas. In: V.C. Sales (org.), Ecossistemas Brasileiros: manejo e conservação. Expressão Gráfica e Editora, Fortaleza, p. 129-142.

Scariot, A.; Lleras, E. \& Hay, J.D. 1995. Flowering and fruiting phenologies of the palm Acrocomia aculeata: patterns and consequences. Biotropica 27: 168-173.

Silva, P.A. \& Scariot, A. 2013. Phenology, biometric parameters and productivity of fruits of the palm Butia capitata (Mart.) Beccari in the Brazilian cerrado in the north of the state of Minas Gerais. Acta Botanica Brasilica 27: 580-589.

Tucker Lima, J.M.; Caruso, N.M.; Clugston, J. \& Kainer, K.A. 2018. Landscape change alters reproductive phenology and sex expression in Attalea palms (Arecaceae) of southwestern Amazonia. Plant Ecology 219: 1225-1245.

White, A.S.; Cook, J.E. \& Vose, J.M. 1991. Effects of fire and stand structure on grass phenology in a ponderosa pine forest. American Midland Naturalist 126: 269-278.

Williams, P.R.; Congdon, R.A.; Grice, A.C. \& Clarke, P.J. 2005. Germinable soil seed banks in a tropical savanna: seasonal dynamics and effects of fire. Austral Ecology 30:79-90.

Wolkovich, E.M. \& Ettinger, A.K. 2014. Back to the future for plant phenology research. New Phytologist 203: 1021-1024. 